\title{
Agrowisata Berbasis Usahatani Padi Sawah Tradisional Sebagai Edukasi Pertanian (Studi Kasus Desa Wisata Pentingsari)
}

\section{Agrowisata Traditional Rice-Based Farming for Agricultural Education (Case Study of Village Tourism Pentingsari)}

\author{
Sugiharti Mulya Handayani ${ }^{1^{*}}$ \\ Fakultas Pertanian Universitas Sebelas Maret, Jl. Ir. Sutami 36/A Kentingan, Surakarta, Indonesia
}

Diterima: 22 Agustus 2016; Direvisi: 27 Oktober 2016; Disetujui: 23 Desember 2016

\begin{abstract}
ABSTRAK
Perkembangan pembangunan terutama di kota besar berdampak pada semakin berkurangnya lahan pertanian padi. Kondisi ini membuat generasi muda terutama yang tinggal di kota besar tidak mengenal proses usahatani padi yang berdampak pada sikap kurang menghargai pangan dan petani yang menghasilkannya. Dampak yang lebih mengkhawatirkan adalah semakin menurunnya minat generasi muda dalam pertanian. Saat ini di DIY berkembang agrowisata berbasis usahatani padi sawah tradisional dengan pelajar sebagai pangsa pasarnya. Penelitian ini bertujuan untuk mengkaji potensi agrowisata berbasis usahatani padi sawah tradisional sebagai edukasi pertanian bagi generasi muda dan mengkaji manfaat sosial ekonominya bagi petani dan masyarakat sekitar. Penelitian ini bersifat deskriptif, dan merupakan sebuah studi kasus di Desa Wisata Pentingsari. Pengumpulan data dan informasi dilakukan dengan cara wawancara mendalam (depth intreview) dengan pengelola agrowisata. Hasil kajian menunjukkan bahwa agrowisata berbasis usahatani padi sawah tradisional berpotensi untuk dikembangkan. Hal ini bisa dilihat dari semakin banyaknya wisatawan pelajar yang berkunjung untuk menikmati dan terlibat dalam pengolahan sawah (bajak sawah, tandur, maupun panen). Secara ekonomi, agrowisata berbasis usahatani padi sawah tradisional dapat meningkatkan pendapatan petani dan masyarakat, sedangkan secara sosial budaya, agrowisata ini turut menjaga kelestarian dan kearifan lokal dalam pengelolaan usahatani padi sawah tradisional.
\end{abstract}

Kata kunci: agrowisata; usahatani; padi sawah; tradisional; edukasi

\begin{abstract}
The development progress, especially in big cities, has given impacts on the decrease of farmlands rice paddy. This condition has made young generations, especially those living in big cities, do not know the process of rice farming which leads to inappropriate attitude of lack of respect for food and farmers who produce it. A more concerning impact is the declining interest of young generations in agriculture. Currently, traditional rice farm based agro tourism is developing in DIY with students as its market share. This research aims to study the potentials of traditional rice farm based agro tourism as an agricultural education for the young generations and also examine the socio-economic benefits for farmers and the surrounding communities. This research was a descriptive study and also a case study at Pentingsari Tourism Village. Data and information was collected through depth interviews with the agro tourism management. Results of study showed that the traditional rice farm based agro tourism has the potential to be developed. This can be seen from the increasing number of student tourists visiting to enjoy and get involved in the processing of the rice fields (rice field plowing, rice paddy planting, and even rice paddy harvesting). Economically, the traditional rice farm based agro tourism can increase the income of farmers and the community, while in terms of socio-cultural, this agro tourism has also preserved local wisdom in managing traditional rice paddy farming.
\end{abstract}

Keywords: agro tourism; farm; rice; traditional; education

\section{Pendahuluan}

Indonesia dikenal sebagai negara agraris yang dicirikan dengan bidang pertanian merupakan mata pencaharian sebagian besar penduduknya. Walau trendnya semakin menurun, banyaknya penduduk yang bergantung di sektor http://www.habitat.ub.ac.id, ISSN: 0853-5167 (p); 2338-2007 (e) 
pertanian masih menduduki peringkat teratas dibanding sektor-sektor yang lain. Selain itu, dengan melihat perkembangan penduduk Indonesia yang cukup tinggi yang berarti kebutuhan pangan akan semakin meningkat maka pembangunan sektor pertanian tetap harus menjadi prioritas. Dengan melihat kenyataan bahwa semakin lama jumlah penduduk yang menggeluti bidang pertanian semakin menurun maka perhatian terhadap sektor pertanian harus ditingkatkan. Saat ini mulai timbul kekhawatiran, Indonesia sebagai Negara agraris terancam kehilangan petani sebagai akibat minimnya regenerasi.

Beberapa kondisi diduga menjadi penyebab turunnnya minat penduduk menjadikan bidang pertanian sebagai lapangan pekerjaan utama. Diantaranya adalah semakin sempitnya kepemilikan lahan usahatani sehingga tidak cukup untuk menjamin kebutuhan hidup keluarga. Semakin sempitnya kepemilikan lahan usahatani ini selain disebabkan karena fragmentasi juga disebabkan semakin maraknya alih fungsi lahan. Selain itu sejalan dengan kemajuan teknologi, industri juga berkembang pesat dan mampu menarik tenaga kerja muda di pedesaan. Generasi muda lebih menyukai bekerja di sektor industri yang dianggap "bersih" dibandingkan bekerja di sektor pertanian yang masih dianggap sebagai bidang pekerjaan yang "kotor". Walaupun pendapatan yang diterima di bidang industri tidak lebih baik daripada hasil usahatani, jaminan upah yang kontinyu juga menjadi daya tarik bagi generasi muda untuk bekerja di sektor industri dibanding di sektor pertanian yang hasilnya bersifat musiman.

Alih fungsi lahan yang berkembang pesat di kota-kota besar menyebabkan hilangnya sawah-sawah produktif. Hal ini menyebabkan generasi muda yang tinggal di perkotaan tidak mengenal sawah yang berdampak pada kurangnya penghargaan pada makanan yang setiap hari dikonsumsi dan petani yang menghasilkannya. Memperhatikan fenomena di atas, maka perlu dicari upaya untuk mengenalkan generasi muda pada pertanian agar berminat pada pertanian.

Dewasa ini pertanian mempunyai potensi yang prospektif untuk dikembangkan sebagai objek wisata atau yang lebih dikenal dengan istilah agrowisata. Agrowisata memberikan

\footnotetext{
${ }^{*}$ Penulis Korespondensi.

E-mail: nanisugeng@yahoo.co.id
}

kesempatan kaum tani meningkatkan kualitas hidupnya dengan memanfaatkan sumber daya pertanian yang mereka miliki (Utama, 2015). Pendapat ini sejalan dengan Rilla, et al (1999) yang menyatakan pembangunan pariwisata mestinya dapat menjadi peluang bagi petani lokal meningkatkan pendapatan untuk mempertahankan hidup keluarganya. Sementara itu hasil kajian Nnadi and Akwiru (2005) di Nigeria menunjukkan bahwa sumberdaya pertanian yang melimpah berpotensi untuk dikembangkan sebagai agrowisata. Oleh sebab itu, pemerintah bekerja sama dengan pihak swasta karena agrowisata akan berkontribusi dalam perkembangan perekonomian.

Berkembangnya agrowisata di seluruh dunia tidak luput dari bergesernya trend pariwisata secara global. Selama dua dekade terakhir telah terjadi pergeseran yang signifikan dari minat terhadap destinasi wisata. Hal ini dapat dilhat dari terjadinya pergeseran orientasi motivasi kunjungan wisatawan dari mass tourism (wisata massal) kepada suatu bentuk kunjungan individual/kelompok kecil yang berminat pada kehidupan keseharian Machin dalam Dinas Pariwisata DIY ${ }^{\mathrm{a}}$ (2014). Pergeseran trend pariwisata secara global membuat agrowisata berkembang pesat di seluruh belahan dunia.

Di Indonesia pergeseran trend minat pariwisata ini disikapi dengan berkembangnya Desa Wisata yang sebagian besar berbasis pada agro (pertanian). Desa wisata merupakan salah satu jawaban dari perkembangan kecenderungan pergeseran tersebut. Wisatawan dengan berbagai motivasi melakukan perjalanan wisata ke desa wisata untuk bisa menikmati kehidupan masyarakat, berinteraksi secara aktif dalam berbagai aktivitas di lokasi desa wisata dan belajar kebudayaan lokal setempat dimana sebagian besar kebudayaan lokal ini merupa kegiatan pertanian (Utama, 2015).

Dari berbagai obyek wisata yang ditawarkan sebuah desa wisata, saat ini yang sedang menjadi trend dan banyak berkembang adalah obyek wisata budaya lokal pengolahan usahatani padi sawah secara tradisional (bajak sawah, tandur dan panen ). Di beberapa daerah di Indonesia, proses pengolahan usahatani padi sawah secara tradisional menjadi komoditas pariwisata yang banyak diminati. Demikian juga dengan desa wisata yang tersebar di Daerah Istimewa Yogyakarta, beberapa diantaranya menyertakan budaya pengolahan usahatani padi sawah sebagai obyek wisata yang ditawarkan. Salah satu desa wisata berbasis usahatani padi http://www.habitat.ub.ac.id, ISSN: 0853-5167 (p); 2338-2007 (e) 
sawah tradisional yang banyak diminati wisatawan pelajar dari kota-kota besar di Indonesia adalah Desa Wisata Pentingsari yang berada di Kabupaten Sleman DIY. Fenomena ini sangat logis mengingat semakin langkanya persawahan di kota-kota besar sehingga desa wisata yang menawarkan proses pengolahan usahatani padi sawah tradisional menjadi atraksi yang menarik dan merupakan wahana edukasi untuk mengenalkan proses usahatani padi kepada pelajar sebagai generasi muda.

Dari uraian di atas maka tujuan dari penelitian ini adalah:

a. Untuk mengetahui potensi agrowisata berbasis usahatani padi sawah tradisional sebagai edukasi pertanian bagi generasi muda.

b. Mengetahui manfaat sosial ekonomi agrowisata berbasis usahatani padi sawah tradisional bagi petani dan masyarakat sekitar.

\section{Metode Penelitian}

Penelitian ini bersifat deskriptif yaitu penelitian yang betujuan untuk melukiskan fakta, populasi atau bidang tertentu secara faktual dan sistematis. Simamora (2004) mendefiniskan penelitian deskriptif adalah prosedur pemecahan masalah yang diselidiki dengan menggambarkan keadaan subyek atau obyek penelitian (orang, lembaga, masyarakat dan lain-lain) pada saat sekarang dan berdasarkan fakta-fakta yang tampak atau sebagaimana adanya. Nazir (2011) menyatakan metode deskriptif adalah suatu metode dalam meneliti status sekelompok manusia, suatu objek, suatu sistem kondisi, suatu sistem pemikiran ataupun suatu kelas peristiwa pada masa sekarang.

Penelitian ini merupakan studi kasus di Desa Wisata Pentingsari yang berada di Kabupaten Sleman. Penelitian dilakukan di Desa Wisata Pentingsari karena merupakan desa wisata yang dikelola secara profesional dan menawarkan budaya pengolahan padi sawah secara tradisisional (bajak sawah, tandur dan panen) sebagai salah satu obyek wisatanya. Desa Wisata Pentingsari merupakan salah satu desa wisata yang secara resmi dipasarkan oleh Dinas Pariwisata DIY dalam Tourism Destination Village (Dinas Pariwisata ${ }^{\mathrm{b}}$, 2015).

Data dan informasi yang digunakan dalam penelitian ini adalah data primer dan data sekunder yang diperoleh melalui observasi dan dept interview (wawancara mendalam) dengan pengelola Desa Wisata Pentingsari. Wawancara mendalam adalah cara wawancara secara langsung yang tidak terstuktur dan dilakukan secara mendalam terhadap individu untuk mendapatkan data atau informasi yang sangat rinci (Simamora, 2004).

\section{Hasil dan Pembahasan}

\subsection{Potensi Agrowisata Berbasis Usahatani Padi Sawah Tradisional Sebagai Edukasi Pertanian}

Atraksi pengolahan usahatani padi sawah secara tradisional sebagai edukasi pertanian banyak diminati wisatawan. Dewasa ini orang tua dan sekolah cenderung memilih membawa anak dan siswanya untuk mengunjungi daerah wisata yang bersifat edukasi dibanding daerah wisata yang hanya bersifat hiburan. Salah satu wisata edukasi yang sekarang sedang menjadi trend adalah live-in di sebuah desa wisata berbasis agro dengan mengikuti semua aktivitas petani dalam mengelola sawahnya. Hal ini sejalan dengan Utama (2015) yang menyatakan bahwa dalam mengunjungi sebuah desa wisata berbasis usahatani padi sawah tradisional, orang tua ingin anak-anak mereka dapat mengetahui dari mana sebenarnya makanan itu berasal. Proses pengolahan usahatani padi sawah tradisional merupakan salah satu cara mengenalkan kepada pelajar sebagai generasi muda tentang asal makanan.

Tabel 1. Jumlah Pelajar Live-in Di Desa Wisata Pentingsari Januari 2015 -Juli 2016

\begin{tabular}{|c|c|c|c|c|}
\hline \multirow[b]{2}{*}{ Bulan } & \multicolumn{2}{|l|}{2015} & \multicolumn{2}{|c|}{ 2016* } \\
\hline & $\begin{array}{c}\text { Pengunjung } \\
\text { total }\end{array}$ & $\begin{array}{l}\text { live- } \\
\text { in }\end{array}$ & $\begin{array}{c}\text { Pengunjung } \\
\text { Total }\end{array}$ & $\begin{array}{l}\text { Live - } \\
\text { in }\end{array}$ \\
\hline Januari & 346 & 205 & 1209 & 165 \\
\hline Pebruari & 762 & - & 2518 & 570 \\
\hline Maret & 1824 & 720 & 2940 & 757 \\
\hline April & 2489 & 231 & 2789 & 665 \\
\hline Mei & 5613 & 1700 & 3475 & 2047 \\
\hline Juni & 2891 & 833 & 542 & - \\
\hline Juli & 1675 & 465 & 1253 & - \\
\hline Agustus & 1787 & 120 & & \\
\hline September & 2118 & - & & \\
\hline Oktober & 2818 & 805 & $240 * *$ & $240 * *$ \\
\hline Nopember & 2565 & 1834 & & \\
\hline Desember & 3878 & & & \\
\hline Total & 28.654 & 6913 & & 4444* \\
\hline Sumber & $\begin{array}{l}\text { Admi } \\
\text { Penti }\end{array}$ & asi & $\mathrm{Wi}$ & \\
\hline
\end{tabular}

Keterangan: * data tersedia sampai bulan Juli ** dalam pesanan 
Sebagai upaya melestarikan kearifan lokal dalam proses penanaman padi secara tradisional dan sebagai media edukasi kepada generasi muda, Desa Wisata Pentingsari menawarkan berbagai atraksi yang berkaitan dengan proses penanaman padi kepada pengunjung. Proses penanaman padi yang ditawarkan adalah bajak sawah, tandur dan panen. Dengan pengemasan atraksi yang menarik, dari tahun ke tahun jumlah wisatawan yang berkunjung ke Desa Wisata Pentingsari selalu meningkat. Peningkatan jumlah pengunjung terutama pengunjung pelajar yang live-in dan belajar usahatani padi sawah tradisional memberi harapan edukasi pertanian melalui wisata akan berdampak positif untuk menumbuhkan minat generasi muda dalam pertanian. Peningkatan jumlah pengunjung juga berdampak positif bagi masyarakat setempat terutama dalam bidang perekonomian. Berikut adalah data pengunjung Desa Wisata Pentingsari dari Januari 2015 sampai Juli 2016.

Pada Tabel 1. dapat diketahui perkembangan jumlah pengunjung desa wisata Pentingsari selama 2 tahun terakhir. Dengan jumlah pengunjung yang mendekati angka 30.000 setiap tahun menunjukkan bahwa desa wisata ini mempunyai daya tarik tersendiri untuk dikunjungi. Data di atas juga menunjukkan bahwa pengunjung yang live-in pada tahun 2015 sebanyak $24 \%$ dan 28,5\% pada tahun 2016 (perhitungan sampai bulan Juli 2016). Pengunjung live-in adalah pengunjung yang tinggal di lokasi desa wisata selama 3 hari dan mengikuti semua aktivitas petani terutama dalam pengelolaan usahatani padi sawah tradisional.

Pelajar yang live - in di desa wisata Pentingsari sebagian besar berasal dari kota-kota besar terutama Jakarta dan Surabaya. Hal ini logis mengingat di kota-kota besar lahan sawah semakin sulit ditemui. Selama live-in di DesaWisata,pelajar tinggal di rumah-rumah penduduk yang merangkap sebagai homestay. Pelajar belajar dan terlibat langsung dalam kehidupan sehari-hari petani terutama dalam mengelola usahatani padi sawah. Mempelajari proses usahatani padi, pelajar terlibat langsung dalam kegiatan bajak sawah dengan tenaga hewan (kerbau), tandur dan panen.

Tingginya animo pelajar untuk live-in di desa wisata berbasis usahatani padi sawah tradisional menunjukkan bahwa agrowisata ini berpotensi untuk dikembangkan. Tidak sekedar sebagai penambah pendapatan petani, lebih jauh agrowisata berbasis usahatani padi sawah tradsional ini bisa menjadi media pembelajaran bagi generasi muda tentang pertanian. Dengan terlibat langsung dalam aktivitas petani mengelola sawahnya diharapkan generasi muda bisa menghargai pangan dan petani yang menghasilkannya . Dalam jangka panjang diharapkan dapat menumbuhkan minat generasi muda untuk menekuni bidang pertanian sehingga kekhawatiran banyak pihak bahwa beberapa tahun yang akan datang Indonesia kehilangan petani tidak menjadi kenyataan.

\subsection{Manfaat Sosial Ekonomi Agrowisata Berbasis Usahatani Padi Sawah Tradisional Bagi Petani dan Masyarakat}

Sejalan berkembangnya waktu mulai disadari bahwa pertanian tidak hanya berfungsi sebagai penghasil pangan namun mempunyai banyak peran atau multifungsi (Subejo, 2012). Agrowisata sebagai salah satu multifungsi dari pertanian berkembang pesat di seluruh belahan dunia karena terbukti memberikan dampak posistif bagi masyarakat. Amanor (2013) menyatakan agrowisata merupakan pilihan dalam diversifikasi pertanian di Kansas karena potensinya dalam meningkatkan pendapatan masyarakat. Sedangkan kajian yang dilakukan oleh Hamzah (2012) di Peninsular Malaysia menunjukkan bahwa agrowisata bermanfaat dalam mendorong pembangunan desa berkelanjutan. Agrowisata meningkatkan pemberdayaan sosial masyarakat, memperkuat ikatan sosial antar masyarakat, meningkatkan pendapatan, merupakan diversifikasi kegiatan ekonomi, menyediakan lapangan kerja dan mengentaskan kemiskinan.

Hasil penelitian agrowisata berbasis usahatani padi sawah tradisional di Desa Wisata Pentingsari menunjukkan adanya dua kelompok masyarakat yaitu masyarakat yang terlibat dan tidak terlibat dalam agrowisata. Masyarakat yang terlibat dikelompokan menjadi masyarakat yang terlibat secara langsung dan tidak langsung. Masyarakat yang terlibat langsung dalam agrowisata berbasis usahatani padi sawah tradisional adalah petani dan instruktur atraksi pertanian, sedangkan yang terlibat secara tidak langsung adalah pemilik homestay, kelompok masak, kelompok kesenian, instruktur non pertanian, kelompok pembuat oleh-oleh dan souvenir serta petugas keamanan/juru parkir. Melalui depth interview dengan ketua Desa Wisata Pentingsari diketahui manfaat ekonomi agrowisata berbasis usahatani padi tradisional seperti disajikan pada Tabel 2. berikut ini.

http://www.habitat.ub.ac.id, ISSN: 0853-5167 (p); 2338-2007 (e) 
Tabel 2. Peluang Ekonomi Agrowisata Berbasis Usahatani Padi Sawah Tradisional Bagi Masyarakat

\begin{tabular}{|c|c|c|}
\hline Kelompok Masyarakat & $\begin{array}{l}\text { Peluang } \\
\text { Ekonomi }\end{array}$ & Manfaat \\
\hline \multicolumn{3}{|l|}{ Terlibat langsung } \\
\hline - $\quad$ Petani & $\begin{array}{l}\text { Menyewakan } \\
\text { lahan untuk } \\
\text { demonstrasi } \\
\text { dan sebagai } \\
\text { instruktur }\end{array}$ & $\begin{array}{l}\text { Tambahan } \\
\text { pendapatan }\end{array}$ \\
\hline $\begin{array}{l}\text { - } \\
\text { instruktur } \\
\text { pertanian }\end{array}$ & $\begin{array}{l}\text { Instruktur } \\
\text { pertanian }\end{array}$ & $\begin{array}{l}\text { Tambahan } \\
\text { pendapatan }\end{array}$ \\
\hline \multicolumn{3}{|l|}{ Terlibat tidak langsung } \\
\hline - pemilik homestay & $\begin{array}{l}\text { Menyewakan } \\
\text { kamar untuk } \\
\text { tamu yang } \\
\text { live-in }\end{array}$ & $\begin{array}{l}\text { Tambahan } \\
\text { pendapatan }\end{array}$ \\
\hline - $\quad$ kelompok masak & $\begin{array}{l}\text { Menyediakan } \\
\text { konsumsi } \\
\text { bagi tamu } \\
\text { diacara } \\
\text { seremonial } \\
\text { maupun } \\
\text { keakraban }\end{array}$ & $\begin{array}{l}\text { Tambahan } \\
\text { pendapatan } \\
\text {. }\end{array}$ \\
\hline $\begin{array}{ll}\text { - } & \text { kelompok } \\
\text { kesenian }\end{array}$ & $\begin{array}{l}\text { Penyambutan } \\
\text { tamu dan } \\
\text { hiburan pada } \\
\text { saat ramah } \\
\text { tamah }\end{array}$ & $\begin{array}{l}\text { Tambahan } \\
\text { pendapatan }\end{array}$ \\
\hline $\begin{array}{ll}\text { - } & \text { instruktur non } \\
\text { pertanian } & \end{array}$ & $\begin{array}{l}\text { Memandu } \\
\text { kegiatan non } \\
\text { pertanian } \\
\text { (outbond, } \\
\text { melatih } \\
\text { membuat } \\
\text { kerajinan } \\
\text { janur, } \\
\text { tracking dsb) }\end{array}$ & $\begin{array}{l}\text { Tambahan } \\
\text { pndapatan }\end{array}$ \\
\hline $\begin{array}{ll}\text { - } & \text { kelompok } \\
\text { makanan olahan }\end{array}$ & $\begin{array}{l}\text { Membuat } \\
\text { keripik } \\
\text { jamur, } \\
\text { keripik ubi, } \\
\text { mengolah } \\
\text { kopi dan } \\
\text { makanan } \\
\text { olahan lain }\end{array}$ & $\begin{array}{l}\text { Tambahan } \\
\text { pendapatan }\end{array}$ \\
\hline $\begin{array}{l}\text { - } \begin{array}{l}\text { keamanan/juru } \\
\text { parkir }\end{array}\end{array}$ & $\begin{array}{l}\text { Menjaga } \\
\text { kenyamanan } \\
\text { tamu dan } \\
\text { keamanan } \\
\text { kendaraan } \\
\text { tamu }\end{array}$ & $\begin{array}{l}\text { Tambahan } \\
\text { pendapatan }\end{array}$ \\
\hline
\end{tabular}

Sumber : informasi pengelola Desa Wisata

Pada Tabel 2. dapat diketahui bahwa adanya agrowisata berbasis usahatani padi sawah tradisional sebagai edukasi pertanian memberikan manfaat ekonomi bagi semua masyarakat baik yang terlibat secara langsung atau tidak langsung.

Agrowisata berbasis usahatani padi sawah tradisional di Desa Wisata Pentingsari dapat meningkatkan pendapatan petani dan masyarakat sekitarnya. Manfaat sosial budaya dapat dinikmati semua anggota masyarakat baik yang terlibat dalam agrowisata maupun yang tidak terlibat. Hasil penelitian menunjukkan bahwa agrowisata berbasis usahatani padi sawah menjaga kelestarian budaya lokal, menekan angka kemiskinan, mengurangi pengangguran dan mencegah urbanisasi serta lingkungan yang terjaga. Di Indonesia, peningkatkan pendapatan dalam agrowisata dapat mengurangi kemiskinan dan mencegah urbanisasi (Utama, 2015).

\section{Kesimpulan}

Dari hasil penelitian tentang agrowisata berbasis usahatani padi sawah tradisional sebagai edukasi pertanian di Desa Wisata Pentingsari dapat disimpulkan:

a. Agrowisata berbasis usahatani padi sawah tradisional sebagai edukasi pertanian banyak diminati generasi muda.

b. Agrowisata berbasis usahatani padi sawah tradisional memberikan manfaat meningkatan pendapatan masyarakat yang terlibat secara langsung maupun tidak langsung dalam kegiatan agrowisata.

Implikasi/rekomendasi dari kesimpulan ini adalah agrowisata berbasis usahatani padi sawah perlu dikembangkan karena selain menjadi media edukasi bagi pelajar tentang pertanian juga dapat meningkatkan pendapatan bagi masyarakat. Penelitian lebih lanjut diperlukan untuk mengkaji seberapa besar edukasi pertanian dalam agrowisata berbasis usahatani padi sawah ini dapat merubah mindset generasi muda terhadap pertanian dan seberapa besar peningkatkan pendapatan yang dinikmati masyarakat baik yang terlibat secara langsung maupun tidak langsung dalam agrowisata ini.

\section{Daftar Pustaka}

Amanor, V and Boadu. 2013. Diversification Decisions In Agriculture: The Case Of Agritourism In Kansas. International Food and Agribusiness Management Review. 16 (2). 
Deptan. 2005. Agrowisata Meningkatkan PendapataPetani. http://database.deptan.go/id.

Dinas Pariwisata ${ }^{a}$. 2014. Laporan Kemajuan Kajian Pengembangan Desa Wisata DIY. Dinas Pariwisata. Yogyakarta.

Dinas Pariwisata b. 2015. Tourism Destination Village. Dinas Pariwisata. Yogyakarta.

Hamzah, A. 2012. Socio-economic impact potential of agro tourism activities on Desa Wawasan Nelayan community living in Peninsular Malaysia. African Journal of Agricultural Research. 7(32), 4581-4588.

Nazir. 2011. Metode Penelitian. Bogor : Ghalia Indonesia.

Nnadi and Akwiru. 2005. Potentials Of AgroTourism For Rural Development In Nigeria. Journal Of Agriculture And Social Research (Jasr) 5 (1).

Rilla E. 1999. Bring the City \& Country Together. California Coast and Ocean. Vol. 15, No. 2. 10p

Simamora. 2004. Riset Pemasaran. Falsafah, Teori dan Aplikasi. Jakarta: Gramedia Pustaka Utama.

Subejo. 2012. Understanding The Multifunctionality of Agriculture. Pembangunan Pertanian dan Pedesaan. Bunga Rampai. Jakarta : UI - Press.

Utama, I G B R. 2015. Agrowisata Sebagai Pariwisata Alternatif Indonesia, Solusi Masif Pengentasan Kemiskinan. 